\title{
Health Human Resource Needs of Government Hospitals in the Philippines
}

\author{
Noel D. Lawas, Richard S. Javier, Carl Abelardo T. Antonio, Emerito Jose A. Faraon, \\ Ma. Susan T. Yanga-Mabunga and Eufemia M. Tobias
}

Department of Health Policy and Administration, College of Public Health, University of the Philippines Manila

\begin{abstract}
Objective. To describe the health human resource needs of government hospitals in the Philippines.

Methods. All 733 licensed government hospitals were included in a survey except 75 of them which the Department of Health have been deploying medical specialists and medical officers to augment the needs of these 75 hospitals.

Results. A total of 96 government hospitals responded to the self-administered survey questionnaire sent to them. Analysis showed $20 \%$ to $29 \%$ among the level 2, level 3 and level 4 hospital responders have their Chief of Hospitals still without a master's education degree as required by the Department of Health. Fifty-nine percent (59\%) of all hospitals do not have nearby medical educational institutions while $28 \%$ of them do not have nearby nursing educational institutions.
\end{abstract}

The greatest need, however, is in the adequacy of the number of doctors and nurses. The minimum required number of doctors and nurses has not been met based on the staffing pattern standards set by the Department of Health for the different hospital categories and by the required 40 work hours per week set for civil servants.

Conclusion. The decline in the adequate number of health human resources noted to start when local public hospitals were devolved from the national government to the local government units in 1991. With this inadequacy, one cannot expect these public hospitals to provide even fair quality of hospital care; thus, the need for the national government to intervene.

Key Words: Philippine public hospitals, health human resource needs, staffing needs

\section{Introduction}

The question of "how adequate is the country meeting the health human resource needs of government hospitals?" has always remained an important concern in the field of

Corresponding author: Noel D. Lawas, MD, MPHM

Department of Health Policy and Administration

College of Public Health

University of the Philippines Manila

625 Pedro Gil Street, Ermita, Manila 1000 Philippines

Telephone: +63917 5349496/+63922 8087766

Email: ndlawas@yahoo.com / ndlawas@up.edu.ph health care delivery. It is a major determinant of the state of quality health services of hospitals in the country. It is an indicator of the adequacy of government resources to ensure and sustain the delivery of quality health services by the government hospitals to the people.

It is a common impression that most government hospitals are undermanned. This study tries to emphasize the need to be more specific especially as to the nature and extent of the health human resource needs of government hospitals.

\section{Objective}

This study aims to identify the health human resource needs of government hospitals in the Philippines.

The study specifically intends to:

1. Describe the basic profiles and current performances of level 1, level 2, level 3 and level 4 government hospitals.

2. Identify the health human resource needs of level 1, level 2, level 3 and level 4 government hospitals in the Philippines.

\section{Definitions}

1. Level 1 hospitals - These are emergency hospitals that provide initial clinical care and management to patients requiring immediate treatment as well as primary care on prevalent diseases in the locality. Their clinical services include general medicine, pediatrics, obstetrics and non-surgical gynecology and minor surgery.

2. Level 2 hospitals - These are departmentalized hospitals that provide clinical care and management on the prevalent diseases in the locality including clinical services such as general medicine, pediatrics, surgery and obstetrics and gynecology.

3. Level 3 hospitals - These are departmentalized hospitals that provided clinical care and management on the prevalent diseases in the locality, as well as particular forms of treatment, surgical procedures and intensive care. Clinical services provided in Level 2 hospitals as well as specialty clinical care.

4. Level 4 hospitals - These are teaching and training hospitals with at least one Accredited Residency training program for physicians that provides clinical 
care including specialized and sub-specialized forms of treatment, surgical procedures and intensive care.

\section{Literature Review}

The following are the minimum number of clinical personnel requirements for the different categories of hospitals for licensing purposes..$^{1-4}$ In addition to this staffing standards is the forty hours a week full time service requirement for government employees. ${ }^{5}$

Table 1. Health Human Resource Minimum Staffing Requirements for Hospital Licensing by Hospital Category

\begin{tabular}{|c|c|}
\hline \multicolumn{2}{|r|}{ LEVEL 1} \\
\hline POSITION & REQUIREMENT \\
\hline Physician & 1 at any given time plus one reliever \\
\hline Nurse & $1: 12$ beds at any given time \\
\hline Nursing Attendants & 1:24 beds at any given time \\
\hline \multicolumn{2}{|r|}{ LEVEL 2} \\
\hline Physician & 1:20 beds at any time plus one (1) reliever \\
\hline Chief Nurse/Supervising Nurse & 1 \\
\hline Staff Nurse & $1: 12$ beds at any given time \\
\hline Nursing Atten/MW & $1: 24$ beds at any given time \\
\hline \multicolumn{2}{|r|}{ LEVEL 3} \\
\hline Chief of Clinics & 1 \\
\hline Dept Head & 1/dept \\
\hline Physician & $\begin{array}{l}50 \text { beds \& below }=6 / \text { Every additional } 50 \\
\text { beds }=2\end{array}$ \\
\hline Dentist & 1 \\
\hline Dental Aide & 1 \\
\hline Chief Nurse & 1 \\
\hline Supervising Nurse & $\begin{array}{l}50 \text { beds } \& \text { below }=1 / 51-100 \text { beds }=2 / 101- \\
150 \text { beds }=3 / 151 \text { and above }=4\end{array}$ \\
\hline Head Nurse & 1:15 Staff Nurses \\
\hline Staff Nurse & $\begin{array}{l}\text { 1:12 beds at any given time plus one reliever } \\
\text { for every } 3 \text { nurses }\end{array}$ \\
\hline Staff Nurse (CCU) & $\begin{array}{l}\text { 1:3 Critical Care beds at any given time plus } \\
\text { one reliever for every } 3 \text { nurses }\end{array}$ \\
\hline Nursing Att / MW & $\begin{array}{l}\text { 1:24 beds at any given time plus one reliever } \\
\text { for every } 3 \text { nursing attend/MW }\end{array}$ \\
\hline Nursing Att / MW (CCU) & $\begin{array}{l}\text { 1:15 beds at any given time plus one reliever } \\
\text { for every } 3 \text { nursing attend/MW }\end{array}$ \\
\hline \multicolumn{2}{|r|}{ LEVEL 4} \\
\hline Chief of Clinics & 1 \\
\hline Dept Head & 1/dept \\
\hline Physician & 100 beds $\&$ below $=8 /$ additional $50=3$ \\
\hline Physical Therapist & 1 \\
\hline Dentist & 1 \\
\hline Chief Nurse & 1 \\
\hline Asst Chief Nurse/Training Off & 100 beds $\&$ above $=1$ \\
\hline Supervising Nurse & $\begin{array}{l}50 \text { beds } \& \text { below }=1 / 51-100 \text { beds }=2 / 101- \\
150 \text { beds }=3 / 151 \text { and above }=4\end{array}$ \\
\hline Supervising Nurse (CCU) & 2 \\
\hline Head Nurse & 1:15 Staff Nurses \\
\hline Staff Nurse & $\begin{array}{l}\text { 1:12 beds at any given time plus one reliever } \\
\text { for every } 3 \text { nurses }\end{array}$ \\
\hline Staff Nurse (CCU) & $\begin{array}{l}\text { 1:3 Critical Care beds at any given time plus } \\
\text { one reliever for every } 3 \text { nurses }\end{array}$ \\
\hline Nursing Att / MW & $\begin{array}{l}\text { 1:24 beds at any given time plus one reliever } \\
\text { for every } 3 \text { nursing attend/MW }\end{array}$ \\
\hline Nursing Att / MW (CCU) & $\begin{array}{l}\text { 1:15 beds at any given time plus one reliever } \\
\text { for every } 3 \text { nursing attend/MW }\end{array}$ \\
\hline
\end{tabular}

Available literature gathered on studies of health human resources locally and internationally only emphasized the inadequacy in the number of health personnel in health facilities but none studied the staffing patterns, required qualifications and estimated degree of staff inadequacy ${ }^{6-21}$

\section{Methods}

This study focuses on all 733 licensed government hospitals as provided in a list by the Bureau of Health Facilities of the Department of Health for the year 2012. Excluded from the list are 75 government hospitals who have been receiving doctors deployed by the Health Human Resource Development Bureau of the Department of Health under the Medical Pool Placement and Utilization Program.

A self-administered questionnaire was sent to all of the 658 hospitals included in the list either by fax $(n=20)$, email $(n=16)$ or postal mail $(n=622)$. Postal mail was used for hospitals which cannot be initially contacted by other means of telecommunication.

Variables included as inquiries are service capability licensing category, authorized bed capacity, service performance for 2012 and health human resource staffing pattern based on licensing standards set by the Department of Health.

Analysis of health human resource needs shall involve the computation of the adequacy of the number of health personnel complement based on the standard of 40-hour a week regular work load for a full-time civil servant complemented by the health human resource staffing pattern requirements for hospitals. Thus, given the staffing requirement in Table 1, the number of physicians, nurses and nursing attendants/midwives that are needed to comply with these standards were computed for each hospital and the gaps or deficits of human resources were analyzed.

\section{Results and Discussions}

\section{Respondents' Profile}

A total of 96 government hospitals responded to the survey representing $14.6 \%$ of the total number of hospitals included in the study. Table 2 shows the profile of the respondents based on regional distribution and hospital licensing category.

It will be noted that no responses came from Region 2 and the Autonomous Region of Muslim Mindanao (ARMM). The hospitals of ARMM were not included in the list provided by $\mathrm{DOH}$ because they are under the regulatory supervision of the ARMM-DOH. On the other hand, a review of the government hospitals in region 2 shows most of them are located in remote municipalities. These, together with the low returns from regions CAR, 4B, 5, 9 and 11 (all of which have majority of government hospitals in remote municipalities) may underestimate the absolute picture of the results on health human resource needs in government hospitals in the country of this study. 
Table 2. Regional Distribution of Respondent Hospitals by Hospital Licensing Category

\begin{tabular}{|c|c|c|c|c|c|c|c|c|}
\hline \multirow{3}{*}{ Region } & \multicolumn{6}{|c|}{ Hospital Category } & \multirow{2}{*}{\multicolumn{2}{|c|}{ Grand Total }} \\
\hline & \multicolumn{2}{|c|}{ Level 1} & \multicolumn{2}{|c|}{ Level 2} & \multicolumn{2}{|c|}{ Level $3 \& 4$} & & \\
\hline & No. & $\%$ & No. & $\%$ & No. & $\%$ & No. & $\%$ \\
\hline 1 & 10 & $14 \%$ & 1 & $6 \%$ & 2 & $20 \%$ & 13 & $14 \%$ \\
\hline 3 & 4 & $6 \%$ & & & 1 & $10 \%$ & 5 & $5 \%$ \\
\hline $4 \mathrm{~A}$ & 7 & $10 \%$ & 2 & $12 \%$ & & & 9 & $9 \%$ \\
\hline $4 \mathrm{~B}$ & 2 & $3 \%$ & & & & & 2 & $2 \%$ \\
\hline 5 & & & 1 & $6 \%$ & 1 & $10 \%$ & 2 & $2 \%$ \\
\hline 6 & 19 & $28 \%$ & 4 & $24 \%$ & & & 23 & $24 \%$ \\
\hline 7 & 17 & $25 \%$ & 1 & $6 \%$ & 1 & $10 \%$ & 19 & $20 \%$ \\
\hline 8 & 3 & $4 \%$ & & & & & 3 & $3 \%$ \\
\hline 9 & 1 & $1 \%$ & 1 & $6 \%$ & & & 2 & $2 \%$ \\
\hline 10 & 1 & $1 \%$ & 2 & $12 \%$ & 1 & $10 \%$ & 4 & $4 \%$ \\
\hline 11 & 1 & $1 \%$ & & & 1 & $10 \%$ & 2 & $2 \%$ \\
\hline 12 & 3 & $4 \%$ & 1 & $6 \%$ & & & 4 & $4 \%$ \\
\hline CAR & & & 1 & $6 \%$ & & & 1 & $1 \%$ \\
\hline NCR & 1 & $1 \%$ & 3 & $18 \%$ & 3 & $30 \%$ & 7 & $7 \%$ \\
\hline $\begin{array}{l}\text { Grand } \\
\text { Total }\end{array}$ & 69 & $100 \%$ & 17 & $100 \%$ & 10 & $100 \%$ & 96 & $100 \%$ \\
\hline
\end{tabular}

Table 3 reveals the service performance of the different hospital categories as indicated by their occupancy rates for 2012. Note that $42 \%$ of the respondent hospitals have an occupancy rate of more than $100 \%$. Upon reviewing the individual responses, it is noted that as high as $320 \%$ occupancy rate was reported in a 25-bed hospital and $227 \%$ occupancy rate was reported in a 100-bed hospital. Given these observations, their impact on the results of this study is expected to further underestimate the absolute picture of the health human resource needs if the licensing standards alone shall be used as the basis of determining the health human resource needs of government hospitals.

Table 3. Service Capability and Performance of Government Hospitals by Licensing Category for 2012

\begin{tabular}{cccccccc}
\hline $\begin{array}{c}\text { Authorized } \\
\text { Bed Capacity }\end{array}$ & \multicolumn{3}{c}{ Hospital Category } & \multicolumn{2}{c}{ Grand Total } \\
\cline { 2 - 5 } & Level 1 & Level 2 & Level 3 & Level 4 & & \multirow{2}{*}{ No. } \\
\hline Bed Capacity & No. & No. & No. & No. & No. \\
\hline 25 or less & 40 & 3 & & & 43 & $45 \%$ \\
26 to 50 & 19 & 4 & & & 23 & $24 \%$ \\
51 to 100 & 8 & 5 & 2 & & 15 & $16 \%$ \\
101 to 300 & 2 & 4 & 4 & 2 & 12 & $13 \%$ \\
Above 300 & & 1 & 2 & & 3 & $3 \%$ \\
Grand Total & $\mathbf{6 9}$ & $\mathbf{1 7}$ & $\mathbf{8}$ & $\mathbf{2}$ & $\mathbf{9 6}$ & $\mathbf{1 0 0} \%$ \\
\hline Occupancy Rate & & & & & & \\
\hline $25 \%$ or less & 1 & & & & 1 & $1 \%$ \\
$26 \%$ to $50 \%$ & 3 & 1 & & & 4 & $4 \%$ \\
$51 \%$ to $70 \%$ & 9 & 1 & & 1 & 11 & $11 \%$ \\
$71 \%$ to $90 \%$ & 13 & 1 & 1 & & 15 & $16 \%$ \\
$91 \%$ to $100 \%$ & 8 & 1 & 2 & & 11 & $11 \%$ \\
$101 \%$ and above & 24 & 11 & 4 & 1 & 40 & $42 \%$ \\
N/A & 11 & 2 & 1 & & 14 & $15 \%$ \\
Grand Total & $\mathbf{6 9}$ & $\mathbf{1 7}$ & $\mathbf{8}$ & $\mathbf{2}$ & $\mathbf{9 6}$ & $\mathbf{1 0 0} \%$ \\
\hline
\end{tabular}

Starting from Level 2 and up to Level 4 hospitals, physicians with executive management responsibilities (as Chief of Hospital or Hospital Administrator) and Chief Nurses are further required to have taken up Masters of Hospital Administration or equivalent and Master of Arts in Nursing, respectively. This is the basis for this study to further inquire on the number of health personnel with Master's degree education. Tables 4 and 5 show the results.

Table 4. Number and Percent Distribution of Physician with Master's Degree by Hospital Category

\begin{tabular}{|c|c|c|c|c|c|c|c|c|}
\hline \multirow{3}{*}{$\begin{array}{c}\text { Number } \\
\text { With } \\
\text { Masters }\end{array}$} & \multicolumn{6}{|c|}{ Number of Respondent Hospitals } & \multirow{2}{*}{\multicolumn{2}{|c|}{$\begin{array}{c}\text { Grand } \\
\text { Total }\end{array}$}} \\
\hline & \multicolumn{2}{|c|}{ Level 1} & \multicolumn{2}{|c|}{ Level 2} & \multicolumn{2}{|c|}{ Level 3 \& 4} & & \\
\hline & No. & $\%$ & No. & $\%$ & No. & $\%$ & No. & $\%$ \\
\hline 0 & 30 & $43 \%$ & 5 & $29 \%$ & 2 & $20 \%$ & 37 & $39 \%$ \\
\hline 1 & 26 & $38 \%$ & 4 & $24 \%$ & 1 & $10 \%$ & 31 & $32 \%$ \\
\hline 2 & 5 & $7 \%$ & 4 & $24 \%$ & 1 & $10 \%$ & 10 & $10 \%$ \\
\hline 3 & 1 & $1 \%$ & 2 & $12 \%$ & 1 & $10 \%$ & 4 & $4 \%$ \\
\hline 4 and higher & 1 & $1 \%$ & 1 & $6 \%$ & 4 & $40 \%$ & 6 & $6 \%$ \\
\hline No Response & 6 & $9 \%$ & 1 & $6 \%$ & 1 & $10 \%$ & 8 & $8 \%$ \\
\hline Grand Total & 69 & $100 \%$ & 17 & $100 \%$ & 10 & $100 \%$ & 96 & $100 \%$ \\
\hline
\end{tabular}

From the perspective of health human resource needs, Table 4 above shows that around 29\% of Level 2 hospitals and $20 \%$ of Level 3 and 4 hospitals do not have any physician with a Master's degree in Hospital Administration or its equivalent; thus, this represents an important human resource need that may result in the downgrading of their hospital category in their license to operate.

Table 5. Number and Percent Distribution of Nurses with Master's Degree By Hospital Category

\begin{tabular}{ccccccccc}
\hline \multirow{2}{*}{$\begin{array}{c}\text { No. With } \\
\text { Master of Arts }\end{array}$} & \multicolumn{3}{c}{ Number of Respondent Hospitals } & \multicolumn{2}{c}{$\begin{array}{c}\text { Grand } \\
\text { in Nursing }\end{array}$} & \multicolumn{2}{c}{ Level 1 } & \multicolumn{2}{c}{ Level 2 } & \multicolumn{2}{c}{ Level 3 \& 4 } & \multicolumn{2}{c}{ Total } \\
\cline { 2 - 7 } in No. & $\%$ & No. & $\%$ & No. & $\%$ & No. & $\%$ \\
\hline 0 & 26 & $38 \%$ & 1 & $6 \%$ & 0 & $0 \%$ & 27 & $28 \%$ \\
1 & 17 & $25 \%$ & 5 & $29 \%$ & 0 & $0 \%$ & 22 & $23 \%$ \\
2 & 9 & $13 \%$ & 1 & $6 \%$ & 1 & $10 \%$ & 11 & $11 \%$ \\
3 & 2 & $3 \%$ & 2 & $12 \%$ & 1 & $10 \%$ & 5 & $5 \%$ \\
4 and higher & 9 & $13 \%$ & 8 & $47 \%$ & 7 & $70 \%$ & 24 & $25 \%$ \\
No Response & 6 & $9 \%$ & 0 & $0 \%$ & 1 & $10 \%$ & 7 & $7 \%$ \\
Grand Total & $\mathbf{6 9}$ & $100 \%$ & $\mathbf{1 7}$ & $100 \%$ & $\mathbf{1 0}$ & $100 \%$ & $\mathbf{9 6}$ & $100 \%$ \\
\hline
\end{tabular}

In Table 5, the health human resource need for a master's degree in the nursing service is low at $6 \%$ among Level 2 hospitals without any nurse having a master's degree.

The presence of nearby medical and nursing educational institutions are expected to benefit the local supply of doctors and nurses. To determine the existing situation, an inquiry was included in the survey. Tables 6 and 7 are the findings of this study.

Table 6 shows that there are no nearby medical educational institutions (within $50 \mathrm{kms}$ ) in $60 \%$ of Level 1 and Level 2 hospitals and in $40 \%$ of Level 3 and Level 4 hospitals. This could partly explain the common perception of lack of doctors serving the rural communities in the country. 
Table 6. Number and Percentage of Nearby Medical Educational Institution

\begin{tabular}{ccccccccc}
\hline $\begin{array}{c}\text { Number of } \\
\text { Medical Educ } \\
\text { Institution }\end{array}$ & \multicolumn{3}{c}{ Number of Respondent Hospitals } & \multicolumn{2}{c}{$\begin{array}{c}\text { Grand } \\
\text { Total }\end{array}$} \\
\cline { 2 - 7 } w/in 50 km & Level 1 & \multicolumn{2}{c}{ Level 2 } & \multicolumn{2}{c}{ Level 3 \& 4 } & & No. \\
\cline { 2 - 8 } & No & $\%$ & No. & $\%$ & No. & $\%$ & No. & $\%$ \\
\hline 0 & 42 & $61 \%$ & 11 & $65 \%$ & 4 & $40 \%$ & 57 & $59 \%$ \\
1 & 9 & $13 \%$ & 4 & $24 \%$ & 0 & $0 \%$ & 13 & $14 \%$ \\
2 & 2 & $3 \%$ & 0 & $0 \%$ & 1 & $10 \%$ & 3 & $3 \%$ \\
3 & 3 & $4 \%$ & 1 & $6 \%$ & 0 & $0 \%$ & 4 & $4 \%$ \\
4 and higher & 8 & $12 \%$ & 0 & $0 \%$ & 3 & $30 \%$ & 11 & $11 \%$ \\
No Response & 5 & $7 \%$ & 1 & $6 \%$ & 2 & $20 \%$ & 8 & $8 \%$ \\
Grand Total & $\mathbf{6 9}$ & $100 \%$ & $\mathbf{1 7}$ & $100 \%$ & $\mathbf{1 0}$ & $100 \%$ & $\mathbf{9 6}$ & $100 \%$ \\
\hline
\end{tabular}

Table 7. Number and Percentage of Nearby Nursing Educational Institution

\begin{tabular}{ccccccccc}
\hline $\begin{array}{c}\text { Number of } \\
\text { Nursing Educ }\end{array}$ & \multicolumn{9}{c}{ Number of Respondent Hospitals } & \multicolumn{2}{c}{ Grand Total } \\
\cline { 2 - 7 } Institution & \multicolumn{2}{c}{ Level 1 } & \multicolumn{2}{c}{ Level 2 } & \multicolumn{2}{c}{ Level 3 \& 4 } & & \\
\cline { 2 - 7 } w/in 50 Km & No. & $\%$ & No. & $\%$ & No. & $\%$ & No. & $\%$ \\
\hline 0 & 21 & $30 \%$ & 4 & $24 \%$ & 0 & $0 \%$ & 27 & $28 \%$ \\
1 & 12 & $17 \%$ & 2 & $12 \%$ & 0 & $0 \%$ & 22 & $23 \%$ \\
2 & 2 & $3 \%$ & 4 & $24 \%$ & 1 & $10 \%$ & 11 & $11 \%$ \\
3 & 9 & $13 \%$ & 2 & $12 \%$ & 1 & $10 \%$ & 5 & $5 \%$ \\
4 and higher & 20 & $29 \%$ & 4 & $24 \%$ & 7 & $70 \%$ & 24 & $25 \%$ \\
No Response & 5 & $7 \%$ & 1 & $6 \%$ & 2 & $20 \%$ & 7 & $7 \%$ \\
Grand Total & $\mathbf{6 9}$ & $100 \%$ & $\mathbf{1 7}$ & $100 \%$ & $\mathbf{1 1}$ & $110 \%$ & $\mathbf{9 6}$ & $100 \%$ \\
\hline
\end{tabular}

Table 7 shows a less serious but definitely still a cause for concern, the absence of nursing educational institutions within $50 \mathrm{~km}$ from the Level 2 government hospitals in $24 \%$ of these hospitals.

\section{Health Human Resource Needs of Level One Hospitals}

The analyses of health human resource needs are based on determining the nature and extent of compliance to staffing standards. This is achieved by comparing the actual number of health personnel with the required number according to regulatory standards. Table 8 shows the results for level one hospitals.

Table 8. Summary Results of Health Human Resource Needs for Level One Government Hospitals ( $n=69$ )

\begin{tabular}{lccccc}
\hline $\begin{array}{c}\text { Hospital } \\
\text { Personnel }\end{array}$ & $\begin{array}{c}\text { Number } \\
\text { of } \\
\text { Personnel }\end{array}$ & $\begin{array}{c}\text { Standard } \\
\text { Deviation } \\
\text { of } \\
\text { Personnel }\end{array}$ & $\begin{array}{c}\text { Mean } \\
\text { Number } \\
\text { of } \\
\text { Required } \\
\text { Personnel }\end{array}$ & $\begin{array}{c}\text { Mean of the } \\
\text { Diff between } \\
\text { Number and } \\
\text { Required } \\
\text { Personnel }\end{array}$ & $\begin{array}{c}\text { Percent of Hosp } \\
\text { with }<0 \\
\text { Difference } \\
\text { Between Actual } \\
\text { and Required } \\
\text { Personnel }\end{array}$ \\
\hline MD's & 8.3 & 8.6 & 5 & 3.3 & $28 \%$ \\
Nurses & 19.1 & 21.1 & 10.8 & 8.3 & $26 \%$ \\
$\begin{array}{l}\text { Nursing } \\
\text { Attendants / } \\
\text { Midwife }\end{array}$ & 10.4 & 12.2 & 5.5 & 4.9 & $9 \%$ \\
\hline
\end{tabular}

Results show the following:

1. Analyzing the level one hospitals as a whole will show that the mean number of Doctors, Nurses and Nursing Attendants / Midwives are higher than the mean required number based on the standards adopted by this study. However, the variability is very wide as shown by the corresponding standard deviation. These values would point to the presence of where the actual numbers of health personnel are lower than the required number.

2. Computing for the percentage number of hospitals with less than zero difference between the actual number with the required number, it was noted that more doctors and nurses are needed in order to comply with the standards. These percentage values are $28 \%$ and $26 \%$ for doctors and for nurses, respectively.

\section{Health Human Resource Needs of Level Two Hospitals}

Summary analysis was also done for the results of level two government hospitals. Table 9 shows the results.

Table 9. Summary Results of Health Human Resource Needs for Level Two Government Hospitals ( $n=16)$

\begin{tabular}{lccccc}
\hline $\begin{array}{l}\text { Hospital } \\
\text { Personnel }\end{array}$ & $\begin{array}{c}\text { Number } \\
\text { of } \\
\text { Personnel }\end{array}$ & $\begin{array}{c}\text { Standard } \\
\text { Deviation } \\
\text { of } \\
\text { Personnel }\end{array}$ & $\begin{array}{c}\text { Mean } \\
\text { Number } \\
\text { of } \\
\text { Required } \\
\text { Personnel }\end{array}$ & $\begin{array}{c}\text { Mean of the } \\
\text { Diff between } \\
\text { Number and } \\
\text { Required } \\
\text { Personnel }\end{array}$ & $\begin{array}{c}\text { Percent of Hosp } \\
\text { with }<0 \\
\text { Difference } \\
\text { Between Actual } \\
\text { and Required } \\
\text { Personnel }\end{array}$ \\
\hline $\begin{array}{l}\text { MD's } \\
\begin{array}{l}\text { Staff Nurses } \\
\text { Nursing }\end{array}\end{array}$ & 26.9 & 23.1 & 22.4 & 4.5 & $38 \%$ \\
$\begin{array}{l}\text { Attendants } \\
\text { / Midwife }\end{array}$ & 23.1 & 56.4 & 37.4 & 21.8 & $38 \%$ \\
\hline
\end{tabular}

Results of analysis for level 2 hospitals show the same pattern of results. This pattern is: taking all level 2 respondent hospitals together, the wide variability of the respondents compliance to the required number of health human resource and computing for each hospital's compliance to the standard will show $38 \%$ of them hire less than the required number of personnel for doctors and nurses and $31 \%$ for nursing attendants/ midwives.

Level two hospital respondents were inquired on the number of specialists in the four expected clinical services based on their hospital license category. Table 10 shows the percentage of level 2 hospital respondents with no medical specialist by specialty class.

Table 10. Percentage of Level 2 Hospital Respondents without Medical Specialists $(n=16)$

\begin{tabular}{lc}
\hline Specialty Class & Percent \\
\hline Internist & $13 \%$ \\
Pediatrician & $31 \%$ \\
Obstetrician-Gynecologist & $25 \%$ \\
Surgeon & $13 \%$ \\
Family Medicine & $44 \%$ \\
Anesthesiologist & $25 \%$ \\
\hline
\end{tabular}


Among the four clinical services, it is the performing of surgical procedures that distinguishes level one from level two hospitals - surgical procedures which are allowed among surgeons and obstetrician-gynecologists. The table shows the absence of obstetrician- gynecologists and of surgeons in $25 \%$ and $13 \%$ of the hospitals, respectively. Added to this is the absence of anesthesiologists in $25 \%$ of these hospitals without whom they cannot perform major surgeries.

Other inquiries were asked on the number of other hospital professionals. All level 2 hospitals have at least a pathologist, radiologist, pharmacist and dietician who are either full time or part time except for two (2) hospitals still without radiologist and one without a dietician.

\section{Health Human Resource Needs of Level Three and Level Four Hospitals}

Summary results of the health human resource needs for level three and level four government hospitals shows similar patterns of needs as shown in Table 11. Again, the table shows significant percentages of non-compliance to the minimum standards where $22 \%, 20 \%$ and $50 \%$ of these hospitals do not meet the minimum number of medical doctors, nurses and nursing attendants, respectively.

Table 11. Summary Results of Health Human Resource Needs for Level Three and Four Government Hospitals $(\mathrm{n}=10)$

\begin{tabular}{lccccc}
\hline $\begin{array}{c}\text { Hospital } \\
\text { Personnel }\end{array}$ & $\begin{array}{c}\text { Number } \\
\text { of } \\
\text { Personnel }\end{array}$ & $\begin{array}{c}\text { Standard } \\
\text { Deviation } \\
\text { of } \\
\text { Personnel }\end{array}$ & $\begin{array}{c}\text { Mean } \\
\text { Number } \\
\text { of } \\
\text { Required } \\
\text { Personnel }\end{array}$ & $\begin{array}{c}\text { Mean of the } \\
\text { Diff between } \\
\text { Number and } \\
\text { Required } \\
\text { Personnel }\end{array}$ & $\begin{array}{c}\text { Percent of Hosp } \\
\text { with }<0 \\
\text { Difference } \\
\text { Between Actual } \\
\text { and Required } \\
\text { Personnel }\end{array}$ \\
\hline $\begin{array}{l}\text { MD's } \\
\text { Staff }\end{array}$ & 132.3 & 116.7 & 52.1 & 80.2 & $22 \%$ \\
$\begin{array}{l}\text { Nurses } \\
\text { Nursing }\end{array}$ & 159.3 & 120 & 74.25 & 85.05 & $20 \%$ \\
$\begin{array}{l}\text { Attendants / } \\
\text { Midwife }\end{array}$ & 46.1 & 21.8 & 37.1 & 9.0 & $50 \%$ \\
\hline
\end{tabular}

As level 3 and level 4 hospitals, they are expected to provide medical specialty services. The number of doctors for the different specialties were inquired and the absence of these doctors for each specialty are presented in Table 12.

Based on the above table, many level 3 and level 4 hospitals have specialists from the different specialty classes; however, not all are able to provide a full array of medical specialty services especially in the field of psychiatry, family medicine, EENT and Orthopedics. Still a few are without an internist and a dentist.

As for pathologists, radiologists, pharmacists and dieticians, all but one hospital have at least one part time or full time for each of the ancillary services. This hospital being referred to does not have a dietician.
Table 12. Percentage of Level 3 and Level 4 Hospitals Respondents without Medical Specialists $(n=10)$

\begin{tabular}{lc}
\hline \multicolumn{1}{c}{ Specialty Class } & Percent \\
\hline Internist & $10 \%$ \\
Pediatrician & $0 \%$ \\
Obstetric-Gynecologist & $0 \%$ \\
Surgeon & $0 \%$ \\
Orthopedics & $20 \%$ \\
Anesthetist & $0 \%$ \\
Family Medicine & $30 \%$ \\
Psychiatry & $70 \%$ \\
EENT & $20 \%$ \\
Dentist & $10 \%$ \\
\hline
\end{tabular}

Besides having staff nurses, level 3 and level 4 hospitals are required to recruit chief nurses, assistant chief nurses and supervising nurses. In the ten level 3 and level 4 hospital respondents, all complied with the minimum health human resource standards for nursing service management officers.

\section{Discussion of Results}

Using as the standards for health human resource needs of government hospitals the required 40 hours a week work and the staffing pattern requirements of the Department of Health for licensing of all hospitals to operate, a significant number of them are found to have below the required number of health human resources. These standards were set by the Department of Health to ensure safety in the delivery of treatment services to the patients; thus, the presence of these findings reflect an alarming situation that needs to be addressed and corrected.

As noted in the results, the number of medical doctors (MD's) that is below the required standards ranges from $22 \%$ to $28 \%$ of all hospital respondents. Among staff nurses, the percentage of hospitals having below the required standard also ranges from $20 \%$ to $38 \%$. For nursing attendants and/or midwives, the percentage of hospitals with below the required number is from $9 \%$ to $50 \%$. Upon reviewing all the individual responses of these respondent hospitals, all noncompliant hospitals are noted to be managed by the local government units. These findings indicate that a significant number of local government units do not have the capacity to maintain up to standard the state of health human resources of their hospitals.

This problem may have been existing since the devolution of public hospitals from the national government in 1991. There has been a clamor since then, by a number of local chief executives for the re-nationalization of hospitals devolved to their local government units because of their limited capacity to fund their operations and the findings of this study confirm their claims.

There have been limited attempts by the national government to correct this situation such as renationalization of some local government hospitals and the establishment of the Medical Pool Placement and Utilization Program of the Department of Health (MedPool 
PUP) through DOH Administrative Order 149 s. 2002 and signed by Secretary Manuel Dayrit. The MedPool program is established to augment the lack of medical officers and specialists in public hospitals.

Between the above two options, the MedPool PUP seems to be more feasible; however this will require further studies.

There are other health human resource needs that have been identified. These are:

1. The scarcity of educational institutions for medical and for nursing professions to supply the local health human resource needs of the hospitals.

2. The scarcity of some of the medical specialties in the level 3 and level 4 hospitals.

3. The absence of a full time pathologist or a full time radiologist in some of the hospitals; however, this gap is being addressed by recruiting part time health professionals.

\section{Conclusion}

The current and existing health human resource need in government hospitals is a fundamental problem that the national government must address. This need is the inability of a significant number of local government units to provide the minimum acceptable number of health human resources and mix of medical specialties in public hospitals.

\section{References}

1. Bureau of Health Facilities, Assessment Tool for Licensing Level 1 Hospitals [Online]. 2007 [cited 2013 February]. Available from http://www.doh.gov.ph/system/files/assessment_level1hospital.pdf

2. Bureau of Health Facilities, Assessment Tool for Licensing Level 2 Hospitals [Online]. 2007 [cited 2013 February]. Available from http://www.doh.gov.ph/system/files/assessment_level2hospital.pdf

3. Bureau of Health Facilities, Assessment Tool for Licensing Level 3 Hospitals [Online]. 2007 [cited 2013 February]. Available from http://www.doh.gov.ph/system/files/assessment_level3hospital.pdf

4. Bureau of Health Facilities, Assessment Tool for Licensing Level 4 Hospitals [Online]. 2007 [cited 2013 February]. Available from http://www.doh.gov.ph/system/files/assessment_level4hospital.pdf

5. “Omnibus Rules Implementing Book V of Executive Order 292 and Other Pertinent Civil Service Laws" Civil Service Commission of the Philippines Publication

6. Grundy J, Healy V, Gorgolon L, Sandig E. Overview of devolution of health services in the Philippines. Rural Remote Health. 2003; 3(2):220.

7. Kanchanachitra, Lindelow M, Johnston $\mathrm{T}$, et al. Human resources for health in southeast Asia: shortages, distributional challenges, and international trade in health services. Lancet. 2011; 377(9767):769-81.

8. El-Jardali F, Tchaghchagian V, Jamal D. Assessment of human resources management practices in Lebanese hospitals Assessment of human resources management practices in Lebanese hospitals. Hum Resour Health. 2009; 7:84.

9. Asemahaqn MA. Knowledge and experience sharing practices among health professionals in hospitals under the Addis Ababa health bureau, Ethiopia. BMC Health Serv. Res. 2014; 14:431.

10. Marcus K, Quimson G, Short SD. Source country perceptions, experiences, and recommendations regarding health workforce migration: a case study from the Philippines. Hum Resour Health. 2014; $12: 62$.
11. Leonardia JA, Prytherch H, Ronquillo K, Nodora RG, Ruppel A Assessment of factors influencing retention in the Philippine National Rural Physician Deployment Program. BMC Health Serv Res. 2012; 12:411.

12. Mbindyo P, Gilson L, Blaauw D, English M. Contextual influences on health worker motivation in district hospitals in Kenya. Implement Sci. 2009; 4:43.

13. Bach Xuan Tran, Hoang Van Minh and Nguyen Duc Hinh: "Factors associated with job satisfaction among commune health workers: implications for human resource policies", Glob Health Action 2013, 6: 18619

14. Goel S, Bhatnagar N, Sharma D, Singh A. Bridging the Human Resource Gap in Primary Health Care Delivery Systems of Developing Countries With mHealth: Narrative Literature Review. JMIR Mhealth Uhealth. 2013; 1(2):e25.

15. Kabene SM, Orchard C, Howard JM, Soriano MA, Leduc R.The importance of human resources management in health care: a global context. Hum Resour Health. 2006; 4:20

16. Basu S, Andrews J, Kishore S, Panjabi R, Stuckler D. Comparative performance of private and public healthcare systems in low- and middle-income countries: a systematic review. PLoS Med. 2012; 9(6):e1001244.

17. Labarda MP. Career shift phenomenon among doctors in Tacloban City, Philippines: lessons for retention of health workers in developing countries. Asia Pac Fam Med. 2011; 10:13.

18. Dimaya RM, McEwen MK, Curry LA, Bradley EH. Managing health worker migration: a qualitative study of the Philippine response to nurse brain drain. Hum Resour Health. 2012; 10(1):47.

19. Willis-Shattuck M, Bidwell P, Thomas S, Wyness L, Blaauw D, Ditlopo P. Motivation and retention of health workers in developing countries: a systematic review, BMC Health Serv Res. 2008; 8:247.

20. Edralin D. Issues in Human Resources Management and Approaches to their Solution. Notes on Business Education, De La Salle UniversityCollege of Business and Economics Publication, Vol 4 No 1, JanuaryFebruary, 2001.

21. Herrera ME, Roman F, Alarilla MC. Overview of Health Sector Reform in the Philippines and Possible Opportunities for Public-Private Partnerships. Asian Institute of Management, Working Paper 10-002, 2010. 